\title{
KOMUNITAS UNTUK ALAM: INOVASI LIMBAH AMPAS KOPI DAN EKSTRIM GYM
}

\author{
Vanessa Natanael ${ }^{1)}$, Sidhi Wiguna Teh ${ }^{2)}$
}

1)Program Studi S1 Arsitektur, Fakultas Teknik, Universitas Tarumanagara, vanessanatanael29@gmail.com 2) Program Studi S1 Arsitektur, Fakultas Teknik, Universitas Tarumanagara, sidhi@ft.untar.ac.id

\begin{abstract}
Abstrak
Kebutuhan akan lapangan kerja dikalangan generasi milenial kian meningkat, seiring dengan usia generasi millenial yang berada pada tahap usia produktif. Tak hanya itu perubahan karakteristik generasi millenial yang lebih cepat untuk menikmati dan mencintai kopi. Tak hanya kebutuhan generasi milenial, melainkan prinsip pembangunan berkelanjutan menjadi pertimbangan. Proyek ini bertujuan sebagai sarana untuk membuka lapangan usaha dan membina keakraban khususnya bagi pecinta kopi dan pecinta alam yang dipersatukan melalui gerakan "Hutan Itu Indonesia" (HII). Dimana usaha yang terbentuk memperdayakan limbah ampas kopi (bahan dasar) menjadi wujud usaha pembangunan berkelanjutan. Metode yang digunakan adalah deksriptif, dilakukan pengamatan langsung di lapangan dan analisis data data untuk menentukan kebutuhan ruang hingga didapatkan hubungan ruang serta sirkulasi di dalam tapak. Konsep yang digunakan adalah Kontras - Harmonis, penyatuan antara tipologi kantor (pengambaran inovasi limbah ampas kopi) dan gym (pengambaran ekstrim gym). Wujud yang tampilkan melalui perpaduan massing kotak (kaku) dengan lengkung (dinamis). Penerapan secara artifisial dapat merasakan alam secara tidak langsung, berada di kebun kopi diartifisialkan melalui aromanya (indera penciuman) secara penglihatan dengan penghijauan (indera penglihatan).
\end{abstract}

Kata kunci: inovasi; limbah ampas kopi; milenial; pecinta alam; pecinta kopi

\begin{abstract}
The need for employment among the milenial generation is increasing, along with the age of milenials who are in the productive age stage. Not only that changes in the characteristics of the milenial generation are faster to enjoy and love coffee. Not only the needs of the milenial generation, but the principle of sustainable development is a consideration. The project aims as a means to open up business opportunities and foster intimacy especially for coffee lovers and nature lovers who are united through the movement "Forests That Indonesia" (HII). Where the businesses formed make waste coffee waste (basic material), a form of sustainable development effort. The method used is descriptive, direct observation in the field and analysis of data - data to determine the space requirements to obtain the relationship of space and circulation in the site. The concept used is Contrast - Harmonious, the union between office typology (the depiction of innovative coffee grounds waste) and the gym (extreme depiction of the gym). The form that is displayed through a combination of massing (rigid) with curves (dynamic). Artificial application can feel the nature in an indirect manner, being in a coffee plantation is artificial through its aroma (sense of smell) visually with greening (sense of sight).
\end{abstract}

Keywords: coffee grounds waste; coffee lovers; innovation; milenials; nature lovers

\section{PENDAHULUAN}

Mengapa 2 proyek tersebut bergabung manjadi satu? Hal tersebut dikarenakan 2 proyek tersebut merupakan poyek disebut sebagai Community for Nature, yang berarti komunitas untuk alam. Kedua proyek tersebut tak hanya semata-mata dibentuk begitu saja, melainkan terbentuk oleh Gerakan Hutan Itu Indonesia atau dikenal dengan HII. Gerakan tersebut merupakan sebuah gerakan menggabungkan komunitas untuk membersihkan gunung dan sampah. Komunitas yang bergabung didalamnya yaitu komunitas pencinta kopi dan komunitas 
pencinta alam, yang mana Komunitas pencinta kopi yang diwakili dengan proyek Coffee Grounds Innovation sedangkan Komunitas pencinta alam diwakili dengan proyek Extreme Gym.

Teori generasi milenial berdasarkan tipe dan perilaku, berdasarkan Tabel Stage of Lifecycle generasi milenial masuk kedalam tahap Young Adulthood yang perlu untuk memikirkan rencana kehidupan, dan selecting life's work (menurut Erikson, dalam teori stage of the life cycle), maka pekerjaan menjadi salah satu prioritas utama bagi generasi milenial yang memasuki usia produktif (25-38 tahun).

Generasi milenial mendominasi penduduk di Indonesia pada usia produktif. Tahun 2015 menurut Bappenas terdapat 84 juta jiwa generasi milenial di Indonesia, sementara total penduduk di Indonesia mencapai 225 juta jiwa. Hal tersebut menekankan bahwa 33\% penduduk di Indonesia menupakan generasi milenial. Jika di lihat dari usia produktif 15-64 tahun, maka sebanyak 50\% dari penduduk usia produktif adalah generasi milenial (16-36 tahun) (Yory Sebastian, 2016).

Kopi dikalangan generasi milenial. Amerika serikat sebagai salah satu negara dengan konsumen kopi terbesar di dunia. Kenaikan akan permintaan kopi sekitar 1,5\% per tahun khususnya dalam jangkauan umur 19-34 tahun, menurut Carlos Mera Arzeno, seorang analis komoditas (Rabobank International di London).

Berdasarkan penelitian mengenai meningkatnya permintaan kopi, menurut laporan Bloomberg bahwa generasi milenial menjadi generasi sebagai konsumen kopi terbesar, yaitu $44 \%$ di Amerika Serikat. Menurut National Coffee Association di New York, kenaikan konsumen kopi terjadi secara signifikan di kalangan generasi milenial yaitu berdasarkan perhitungan konsumsi harian terjadi kenaikan $10 \%$ (dari $38 \%$ menjadi $48 \%$ ) pada usia $18-24$ tahun. Tak hanya itu, terjadi kenaikan sebesar $9 \%$ (dari 51\% menjadi 60\%) pada usia 25-39 tahun.

Melalui laporan penelitian tersebut menyebutkan kopi menjadi sebuah life style atau gaya hidup bagi generasi milenial dan generasi Z. Generasi yang lahir setelah tahun 1995 mulai menikmati kopi diusia 14 tahun, sedangkan generasi yang lahir 1980 an mulai menikmati kopi diusia 17 tahun.

Berdasarkan penjelasan di atas, generasi milenial merupakan generasi terbanyak dalam mengkonsumsi kopi, dan menjadi lifestyle (coffee menjadi sebuah kebutuhan bukan lagi keinginan).

Komunitas pencinta kopi di Indonesia mulai muncul dan popular terlebih di kalangan generasi milenial, yaitu “Komunitas Breakfast Ride" merupakan salah satu komunitas pencinta kopi di Indonesia yang berdiri di tahun 2016. Komunitas ini bermula dari kesukaan bersepeda, namun seiring dengan sarapan pagi sebelum bersepeda yang tentunya tak lepas dengan kopi sebagai menu sarapan pagi, maka komunitas ini bukan hanya komunitas bersepeda melainkan komunitas pencinta kopi.

Komunitas Vesparista berasal dari kata vespa dan barista, komunitas ini sudah berdiri selama 2 tahun lamanya sejak 2016. Sesuai dengan namanya maka komunitas ini merupakan komunitas pencinta vespa dan kopi. Komunitas ini menerapkan sistem mengendarai (riding) vespa dari satu coffee shop ke coffee shop berikutnya. Komunitas ini dalam melakukan aktivitasnya melalui agenda yang terjadwal dan aktif di sosial media.

Sustainable Development Goals di Indonesia Limbah terbanyak di indonesia merupakan limbah makanan. Hal tersebut dibuktikan melalui data food sustainability index 2017 dirilis oleh The Economist Intelligence Unit bahwa delam 1 tahun sebanyak 13 juta ton sampah makanan terbuang di Indonesia, yang mana angka terbut dapat memenuhi pangan 28 juta orang, terlebih yang mengalami kemiskinan.

\section{Rumusan masalah}

a. Bagaimana pengaruh dan proses kegiatan proyek Coffee Grounds Recycling Innovation dan Extreme Gym terhadap kehidupan kota dan generasi milenial?

b. Apa saja program dan konsep dalam proyek yang diajukan? 


\section{Pembatasan masalah}

Berdasarkan tema Studio Perancangan Arsitektur 8.27 yaitu milenial, maka proyek difokuskan pada ruang lingkup generasi milenial (tipe, dan perilaku), menyangkut pada kebutuhan, permasalahan, dan solusi untuk kedepannya. Tak hanya itu proyek ini juga di fokuskan kepada Sustainable development goals sebagai solusi bagi generasi milenial. Pembatasan kawasan pengamatan dibatasi dengan berfokus pada Kecamatan Setiabudi, Jakarta Selatan.

\section{Tujuan penelitian}

Tujuan penelitian dari proyek Coffee Grounds Recycling Innovation dan Extreme Gym ditulisakan dalam bentuk visi dan misi, yaitu:

a. Visi terhadap generasi Milenial : Menjadi wadah bagi komunitas pencinta kopi dan pecinta alam yang didominasi oleh generasi milenial. Oleh karena itu menjadi wadah bagi generasi milenial untuk memulai start up (membuka lapangan pekerjaan).

b. Visi terhadap kehidupan kota: Mempekuat interaksi penduduk di kota tersebut, membentuk komunitas. Menigkatkan kondisi perekonomian di kota tersebut. Tak hanya itu, menjadikan pusat/ gerakan melawan global warming.

c. Misi: Menyediakan wadah bagi generasi milenial memulai start up (membuka lapangan pekerjaan) bagi para komunitas pecinta kopi yang menjadikan kopi sebagai sarana memulai usaha.

\section{KAJIAN LITERATUR}

\section{Generasi}

Stage of Life cycle

Maka berdasarkan tabel Teori Stage of Lifecycle generasi milenial masuk kedalam tahap Young Adulthood yang perlu untuk memikirkan rencana kehidupan, dan selecting life's work (Erikson, 1982) maka pekerjaan menjadi salah satu prioritas utama bagi generasi milenial yang memasuki usia produktif (25-38 tahun).

\section{Usia Produktif}

Jika di lihat dari usia produktif 15-64 tahun, maka sebanyak 50\% dari penduduk usia produktif adalah generasi milenial 16-36 tahun (Yoris Sebastian, 2016).

\section{Bebas Bekerja}

Generasi milenial atau generasi langgas, yang mana langgas berarti "bebas". Maka, kebebasan menjadi hal utama bagi generasi milenial terlebih dalam urusan bekerja, generasi milenial lebih memilih untuk menjadi tenaga lepas, dikarenakan fleksibilitas yang tinggi.

Faktor utama yang menjadikan generasi milenial disebut sebagai generasi langgas adalah kemajuan teknologi, yang mana internet mempermudah proses kerja (Yoris Sebastian, 2016).

\section{Penggunaan Media Sosial}

Pengembangan jurnalisme akan memegang kendali digenerasi selanjutnya yaitu generasi " $Z$ ". Maka secara program ruang dibentuk kantor pengelola yang berkaitan sebagai pusat informasi konektivitas penjual dan pembeli hingga (Pew Research Center,2019)

\section{Kopi Dikalangan Generasi Milenial}

Amerika serikat sebagai salah satu negara dengan konsumen kopi terbesar di dunia. Kenaikan akan permintaan kopi sekitar 1,5\% per tahun khususnya dalam jangkauan umur 1934 tahun, menurut Carlos Mera Arzeno, seorang analis komoditas (Rabobank International di London). 
Berdasarkan penelitian mengenai meningkatnya permintaan kopi, menurut laporan Bloomberg bahwa generasi milenial menjadi generasi sebagai konsumen kopi terbesar, yaitu $44 \%$ di Amerika Serikat. Menurut National Coffee Association di New York, kenaikan konsumen kopi terjadi secara signifikan di kalangan generasi milenial yaitu berdasarkan perhitungan konsumsi harian terjadi kenaikan $10 \%$ (dari $38 \%$ menjadi $48 \%$ ) pada usia $18-24$ tahun. Tak hanya itu, terjadi kenaikan sebesar $9 \%$ (dari 51\% menjadi 60\%) pada usia 25-39 tahun.

Melalui laporan penelitian tersebut menyebutkan kopi menjadi sebuah life style atau gaya hidup bagi generasi milenial dan generasi Z. Generasi yang lahir setelah tahun 1995 mulai menikmati kopi diusia 14 tahun, sedangkan generasi yang lahir 1980 an mulai menikmati kopi diusia 17 tahun.

\section{Sustainable Development Goals di Indonesia}

Limbah terbanyak di Indonesia

Limbah terbanyak di indonesia merupakan limbah makanan. Hal tersebut dibuktikan melalui data food sustainability index 2017 dirilis oleh The Economist Intelligence Unit bahwa delam 1 tahun sebanyak 13 juta ton sampah makanan terbuang di Indonesia, yang mana angka terbut dapat memenuhi pangan 28 juta orang, terlebih yang mengalami kemiskinan.

\section{Limbah makanan mendominasi berbagai jenis limbah di dunia}

Menurut laporan worldbank.org, yang mana sebagian besar sampah di dunia berupa sampah organik seperti dari makanan yang kita makan, sisa makanan hewan, dan hortikultura yang mencapai hampir setengah limbah di dunia dengan presentase $46 \%$, disusul kertas dan plastik sebanyak $27 \%$.

Presentase sampah municipal (kota) di Amerika Serikat 2013, yang mana sampah kertas merupakan jenis limbah atau sampah terbanyak dengan $27 \%$, dan diikuti oleh sampah makanan dengan $14,6 \%$ sebagai peringkat kedua.

\section{Teori Arsitektur}

Dasar sistem struktur rangka merupakan struktur dengan sambungan fleksibel di Indonesia. Dikarenakan bentuk dasar yang digunakan adalah bentuk segitiga (triangulasi) dari susunan batang linear dalam keseimbangan gaya tarik dan tekan.Struktur rangka dibentuk guna untuk menciptakan ruang menjadi struktur ruang rangka. Tak hanya itu, guna meningkatkan kekuatan dan kekakuan.

Sistem struktur ruang truss adalah penggabungan sistem struktur rangka ruang yang mampu menutupi ruang besar dari kolom (bentang lebar). Sistem struktur memiliki kelebihan diantaranya yaitu bersifat fleksibel, penggunaannya sangat luas dan bervariasi (struktur, dimensi, profil rangka, dan bahan bangunan struktur).

\section{METODE}

Metode yang digunakan penulis dalam makalah ini adalah model pendekatan riset dengan metode deskriptif. Pengumpulan data dilakukan dengan beberapa cara, yaitu:

\section{a. Kajian Teoritis}

Penelitian ini juga menggunakan berbagai teori yang relevan dengan konteks permasalahan dan menganalisa penelitian-penelitian terdahulu yang sejenis. Kajian teoritis dilakukan dengan cara membaca, menganalisa, meringkas, dan mengutip.

\section{b. Observasi}

Obeservasi dilakukan unutk mengerahui secara langsung kondisi fisik dan kondisi sosial kawasan pengamatan terpilih. Teknik ini dilakukan dengan beberapa kegiatan diantaranya pengamatan kondisi fisik dan sosial, pemetaan, pencatatan dan dokumentasi pribadi. 


\section{c. Data Statistik}

Studi ini juga melakukan pengamatan terhadap data statistik kawasan pengamatan terbaru untuk mengetahui data kuantitatif kawasan demi keakuratan penelitian.

\section{d. Peta Kognitif}

Peta kognitif dibuat untuk memudahkan menganalisa kawasan pengamatan dalam aspek ruang kota, dibidang Arsitektur. Hal ini bertujuan untuk mengetahui ruang kota, jarak, dan lain-lain.

Kajian teoritis yang telah dikumpulkan dan disusun nantinya akan menentukan proyek apa yang akan diusung. Kajian teoritis yang dikumpulkan mengacu pada tema yang telah ditentukan yaitu milenial: tipe dan perilaku, serta penekanan terhadap sustainable development. Setelah menentukan proyek apa yang akan diusung, selanjutnya menentukan lokasi tapak yang sesuai dengan kriteria proyek yaitu:

Tabel 1. Kriteria Tapak Berdasarkan Proyek yang Disusun

\begin{tabular}{|l|l|}
\hline \multicolumn{1}{|c|}{ "Coffee Grounds Innovation" } & \multicolumn{1}{|c|}{ "Extreme Gym" } \\
Kesesuaian: & Kesesuaian: \\
1. Sarana pendidikan & I. Sarana olahraga \\
- Area dengan tingkat pendidikan yang & - Berada diarea dengan jumlah kaum muda \\
minim & (youth)yang tiaggi. \\
2. Sarana tempat kerja & 2. Sarana hiburan \\
- Ada kedekatan dengan institusi yang & - Berada diarea dengan tingkut kesibukan \\
terkat dengan media sosial. & yang tingsi \\
3. Sarana pemasaran & \\
- Berada diarea dengan jumlah warga negara & \\
asing yang banyak (expatriate)
\end{tabular}

Sumber: Penulis, 2019

Melalui kriteria tapak, maka ditentukannya lokasi tapak yaitu berada di Jalan Halimun Raya, Kecamatan Setiabudi, Kota Jakarta Selatan, Provinsi DKI Jakarta. Dengan spesifikasi tapak:

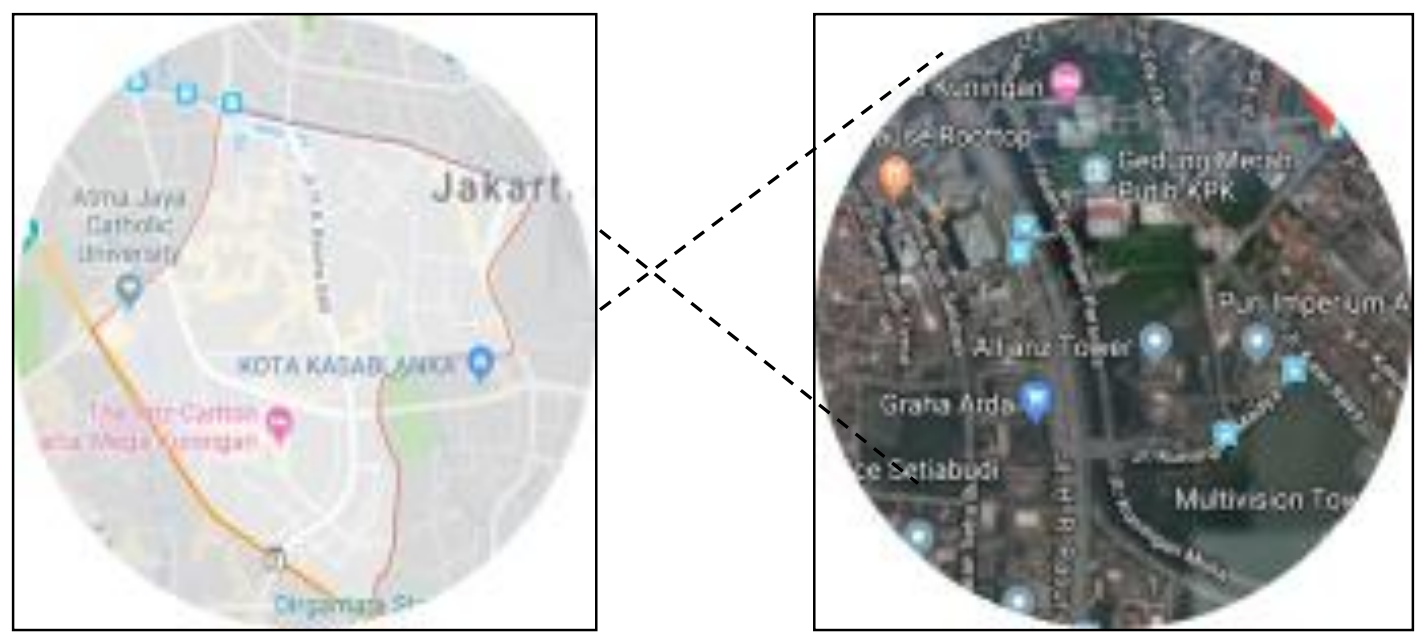

Gambar 1. Lokasi tapak, Kecamatan Setiabudi Sumber: Google maps, 2019 


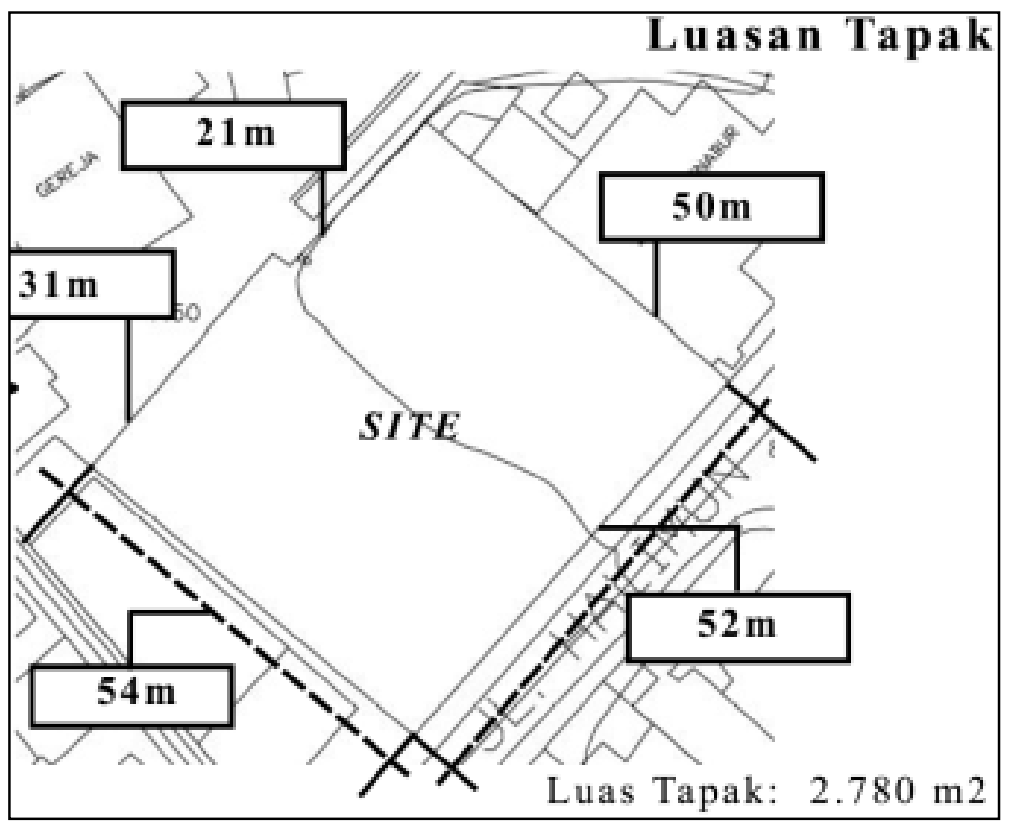

Gambar 2. Luasan Tapak

Sumber: Penulis, 2019

Tabel 2. Profil Tapak

\begin{tabular}{|c|c|}
\hline $\begin{array}{l}\text { Peraturan (zonasi): } \\
\text { Kode lokasi tapak: }\end{array}$ & $\left.\right|_{\text {Peraturan (pembangunan) }}$ \\
\hline ID Subblock : $016 . \mathrm{K} \cdot 1 \mathrm{ab}$ & KDB : $50 \%$ \\
\hline $\begin{array}{lll}\text { Block } & : 04\end{array}$ & I KLB : 3,50 \\
\hline Sub Block & $\mathrm{KDH}: 30 \%$ \\
\hline : Perkantoran,l & KTB : $55 \%$ \\
\hline perdagangan, dan jasa & Tipe : Tunggal \\
\hline
\end{tabular}

Sumber: Rencana Detail Tata Ruang Pemprov. DKI Jakarta.

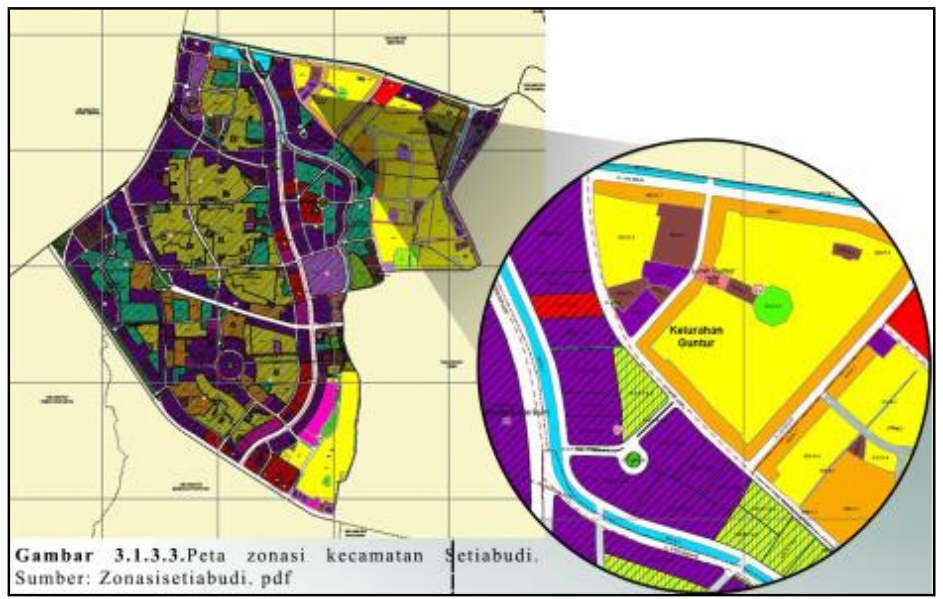

Gambar 3. Peta Zonasi Kecamatan Setiabudi Sumber: Penulis, 2019

Dengan spesifiksi tapak yang telah ada maka dilakukan analisa tapak secara makro, meso, dan mikro. Penekanan proyek khususnya Coffee Grounds Innovation, mengelola limbah ampas kopi, telah di analissa secara mezo yang mana terdapat 19 café di sekitar tapak sebagai syarat atau kriteria proyek berada di lokasi tersebut. Jakarta Selatan menjadi wilayah dengan tingkat café atau tempat penjualan kopi terbanyak. 


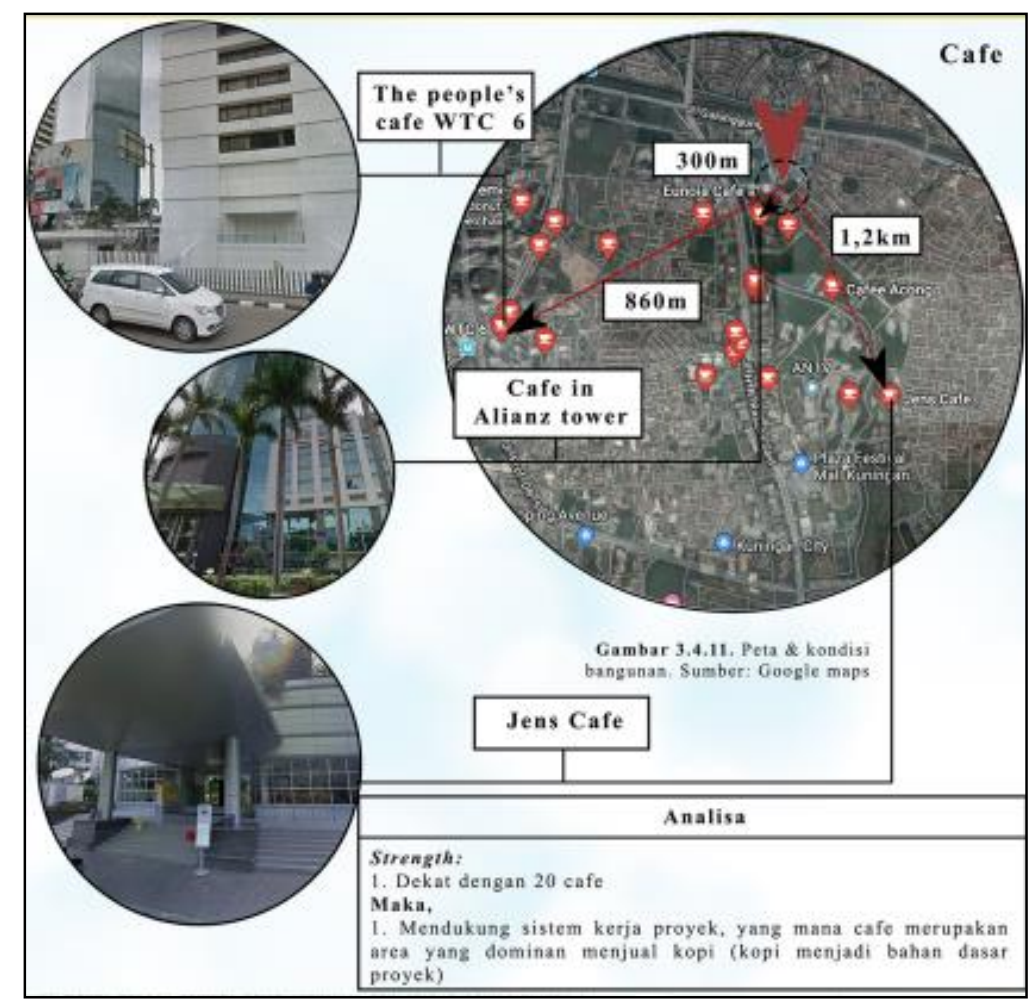

Gambar 4. Analisa Pesaing - Cafe disekitar Tapak Sumber: Penulis, 2019

Dalam tahap perancangan menggunakan metode transprogramming yaitu metode yang mengkombinasikan dua program yang sifat dan konfigurasi spasialnya berbeda tanpa melihat kecocokannya (Tschumi, 2005). Penekanan metode transprograming ditunjukkan pada konsep bangunan yaitu Kontras-Harmonis, baik pada bentuk massing serta kombinasi program. Dilakukan kombinasi antara program Coffee Grounds Innovation (mewakili fungsi tempat kerja) dan Extreme Gym (mewakili fungsi tempat olahraga/ hiburan) yang mana perbedaan terjadi dari segi fungsi, area ruang gerak yang dibutuhkan, serta dari segi kebisingan yang dihasilkan.

\section{DISKUSI DAN HASIL}

Komunitas yang dikenal sebagai komunitas untuk alam ini bertujuan menjadikan komunitas yang tak hanya menyukai atau mengkonsumsi kopi, namun menekuni kopi secara lebih dalam, yaitu menjadikan kopi sebagai lapangan usaha (wadah bagi para start up).Tak hanya itu namun membentuk keakraban antara komunitas pencinta kopi dan pencinta alam dengan saling membantu dalam proses mebentuk produk yang dijalankan sebagai lapangan usaha.

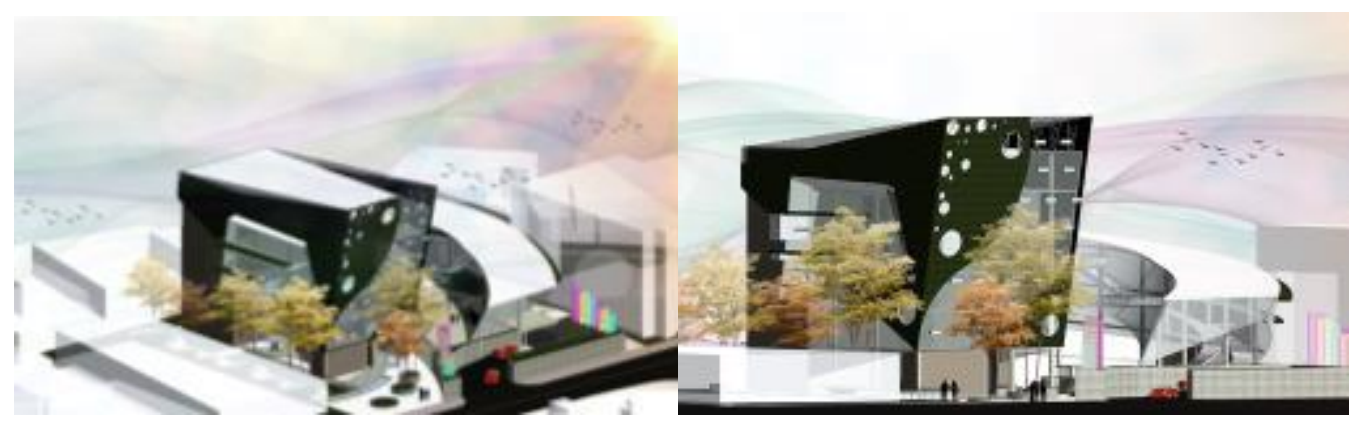

Gambar 5. Perspektif Eksterior

Sumber: Penulis, 2019 
Konsep yang diusung adalah Kontras - Harmonis, penyatuan antara tipologi kantor (pengambaran inovasi limbah ampas kopi) dan gym (pengambaran ekstrim gym). Wujud yang tampilkan melalui perbaduan massing kotak (kaku) dengan lengkung (dinamis). Tak hanya itu penerapan secara artifisial dapat merasakan alam secara tidak langsung, berada di kebun kopi diartificial melalui aromanya (indera penciuman) secara penglihatan dengan penghijauan (indera penglihatan).

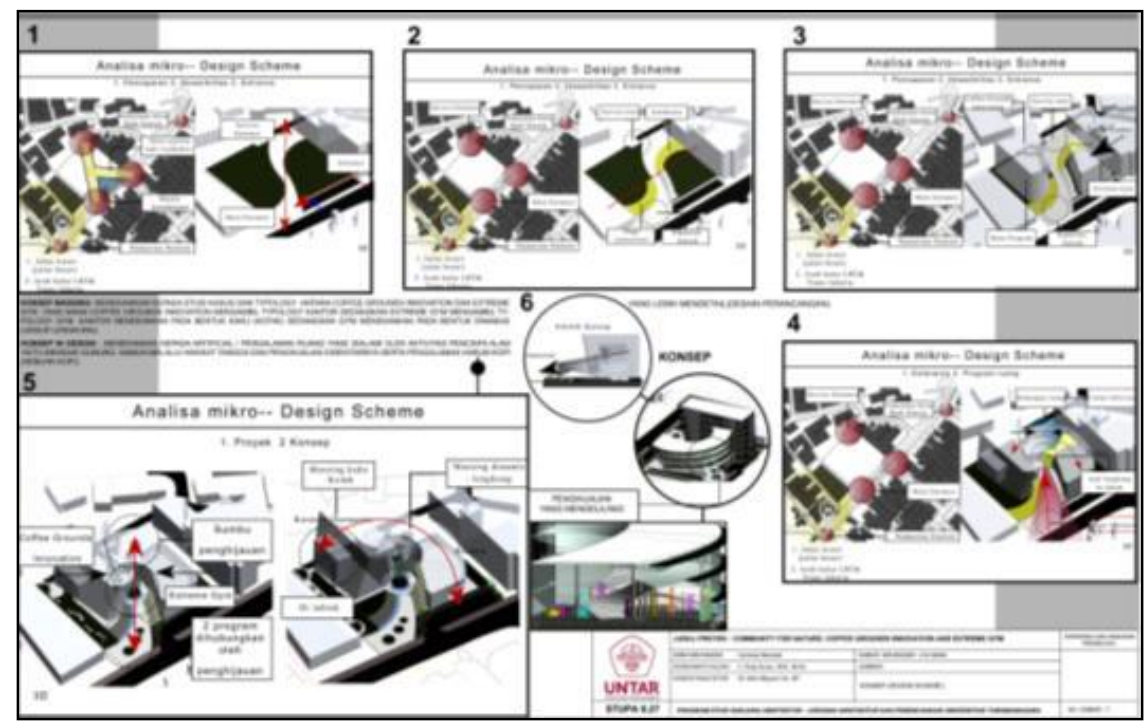

Gambar 6. Design Scheme (konsep)

Sumber: Penulis, 2019

Program ruang berasal dari perpaduan beberapa studi preseden. Coffee Grounds Innovation diwakili dengan 3 preseden, dan begitu pula dengan Extreme Gym. Maka, terbentuk beberapa program ruang di dalamnya dengan program utama yaitu: Coffee Grounds Inovation, Extreme Gym, dan area penunjang. Program utama terbagi lagi menjadi program yang lebih kecil di dalamnya sebagi berikut:

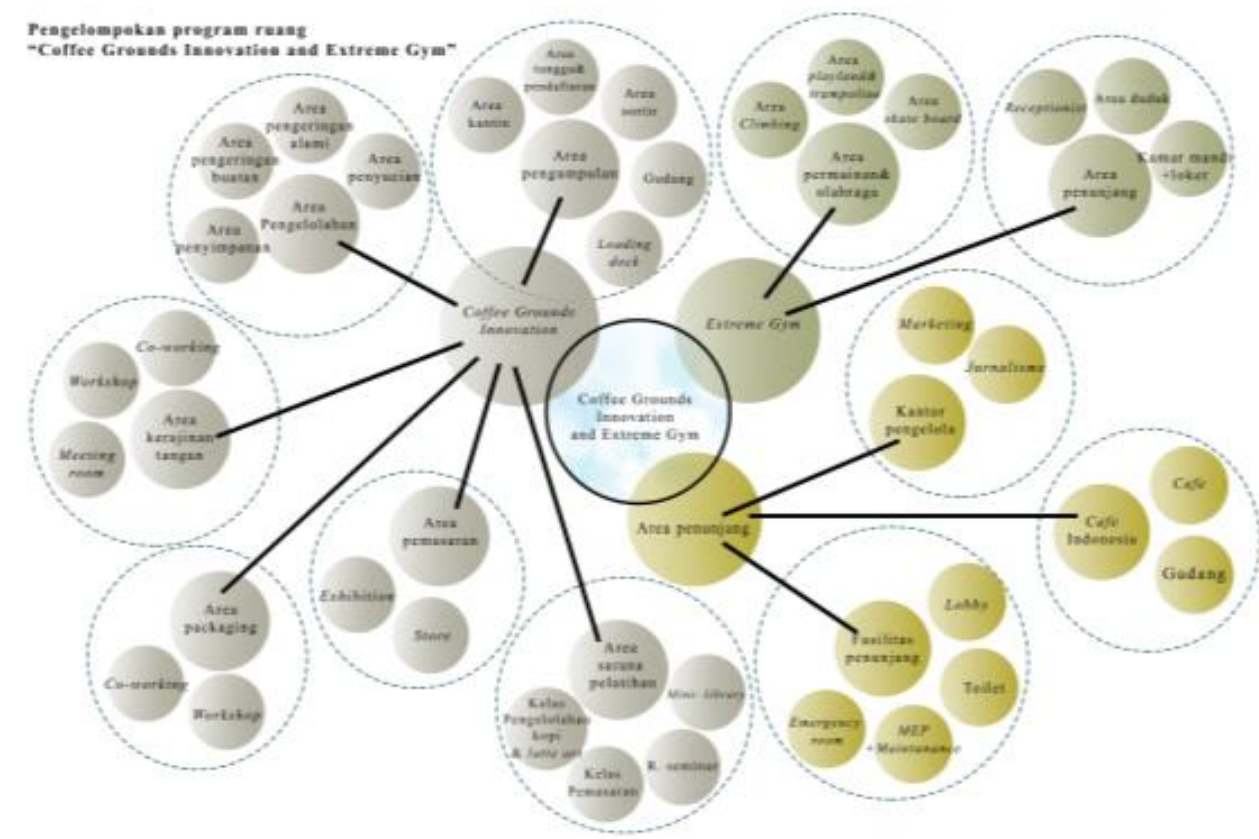

Gambar 7. Pengelompokan Program Ruang

Sumber: Penulis, 2019 
Program ruang yang telah terbentuk, selanjutnya di masukkan kedalam luasan ruang baik luas secara spesifik maupun persenan, yaitu sebagai berikut:

Tabel 3. Pengelompokan Program Ruang

\begin{tabular}{|c|c|c|c|c|c|c|}
\hline Area & Total kapasitas & Luas & & & & \\
\hline \multicolumn{3}{|c|}{ Coffec Grounds Inmovation } & \multicolumn{4}{|c|}{ Area Penunjang } \\
\hline 1. Peagunpalas & 45 arane & $264 \mathrm{~m} 2$ & $\begin{array}{l}\text { 1. Kaater } \\
\text { peseclain }\end{array}$ & \multicolumn{2}{|c|}{40 arase } & $390 \mathrm{mz}$ \\
\hline 2. Peogelahaz & ite erang & $392 \mathrm{mz}$ & & \multirow{2}{*}{\multicolumn{2}{|c|}{68 arant }} & \\
\hline $\begin{array}{l}\text { 3.Kersilsan } \\
\text { tasean }\end{array}$ & 224 erang & $1.440 \mathrm{~m} 2$ & 2. Cafe & & & $468 \mathrm{~m} 2$ \\
\hline 4. Pectaging & 80 erang & $756 \mathrm{~m} 2$ & $\begin{array}{l}\text { 3. Fasilitas } \\
\text { prousjanz }\end{array}$ & \multicolumn{2}{|c|}{219 erana } & $885=2$ \\
\hline $\begin{array}{l}\text { 5. Sarana } \\
\text { pelatibas }\end{array}$ & 372 oranz & $1.107 \mathrm{mi}$ & & \multirow{2}{*}{\multicolumn{2}{|c|}{$\begin{array}{l}464 \text { sepedat } \\
60 \text { mobil }\end{array}$}} & \multirow[b]{2}{*}{$\begin{array}{c}2160 \mathrm{nt} \\
\text { (tidak masuk } \\
\text { KL B) }\end{array}$} \\
\hline $\begin{array}{l}\text { 6. Sarana } \\
\text { Pemasaran }\end{array}$ & 203 arase & $818 \mathrm{~m} 2$ & 4. Parkir & & & \\
\hline \multicolumn{3}{|l|}{ Extreme Gym } & \multicolumn{4}{|c|}{ Kesimpulan Fresentase Ruasg } \\
\hline $\begin{array}{l}\text { 1. Ares } \\
\text { permalnas }\end{array}$ & 604 erang & $3960 \mathrm{~m}^{2}$ & $\begin{array}{l}\text { D.Ceffee } \\
\text { Crouads } \\
\text { Reyeliaz }\end{array}$ & 962 erang & $4.777 \mathrm{~m}=1$ & $53 \%$ \\
\hline \multirow[t]{2}{*}{$\begin{array}{l}\text { 2. Ares } \\
\text { peausjang }\end{array}$} & \multirow[t]{2}{*}{82 eraeg } & \multirow[t]{2}{*}{$315 \mathrm{~m} 2$} & $\begin{array}{l}\text { 2. Extreme Gym } \\
\text { 3. Pesusjasz }\end{array}$ & $\begin{array}{l}637 \text { erang } \\
247 \text { orang }\end{array}$ & $\begin{array}{c}3.315 \mathrm{mz} \\
927 \mathrm{m2}\end{array}$ & $\begin{array}{l}37 \% \\
10 \%\end{array}$ \\
\hline & & & Tetat & $\begin{array}{l}\text { 1. } 596 / \text { maks } \\
1960 \text { araag }\end{array}$ & $6010 \mathrm{~m} 2$ & $100 \%$ \\
\hline
\end{tabular}

Sumber: Penulis, 2019

Program yang tersusun pun mendukung aktivitas proyek yang dibutuhkan didalamnya, maka urutan aktivitas yang terjadi sebagai berikut:

Tabel 4. Alur Kegiatan dan Sequence Bangunan

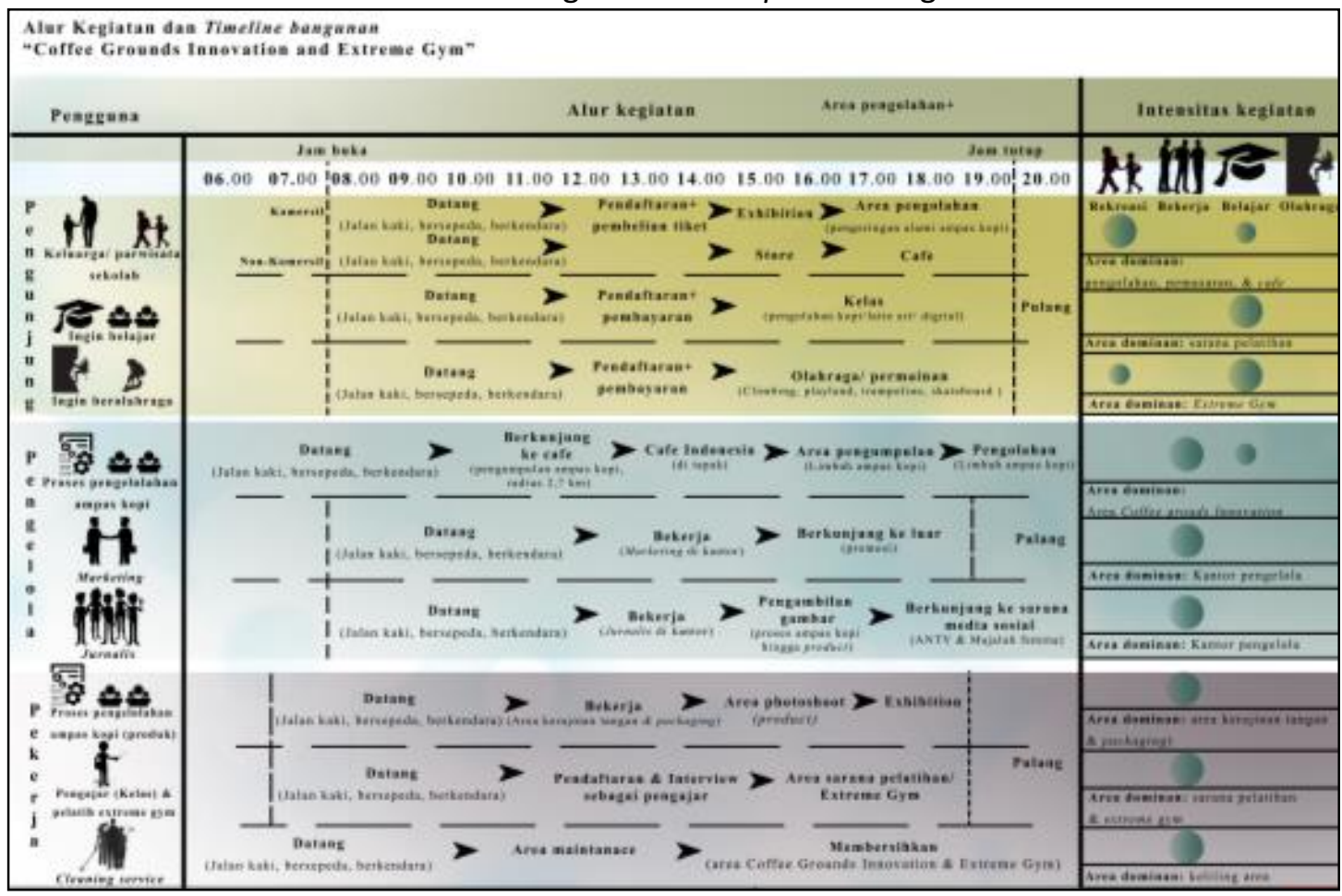

Sumber: Penulis, 2019 
Tabel 5. Skema Kegiatan dan Jadwal Kelas

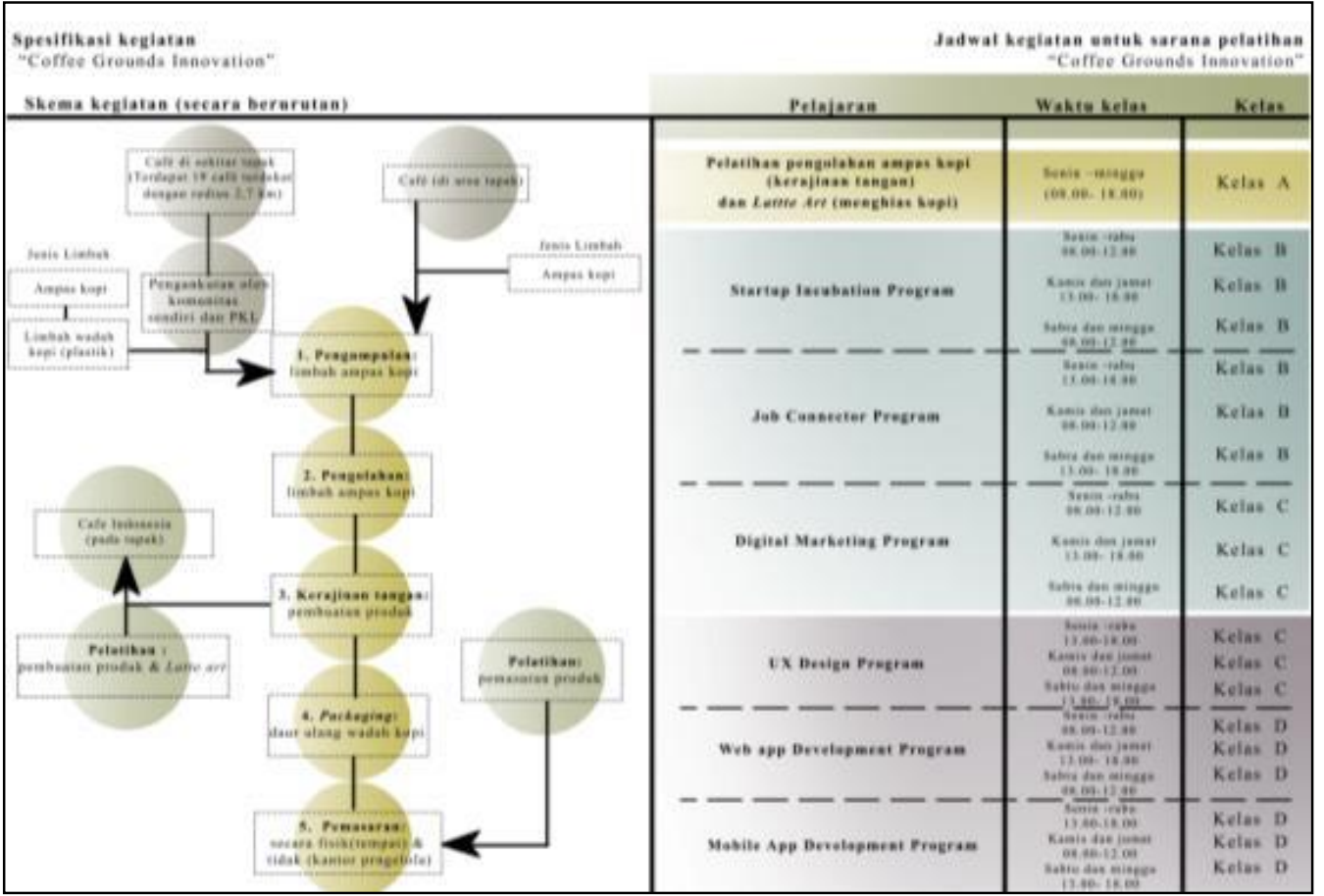

Sumber: Penulis, 2019

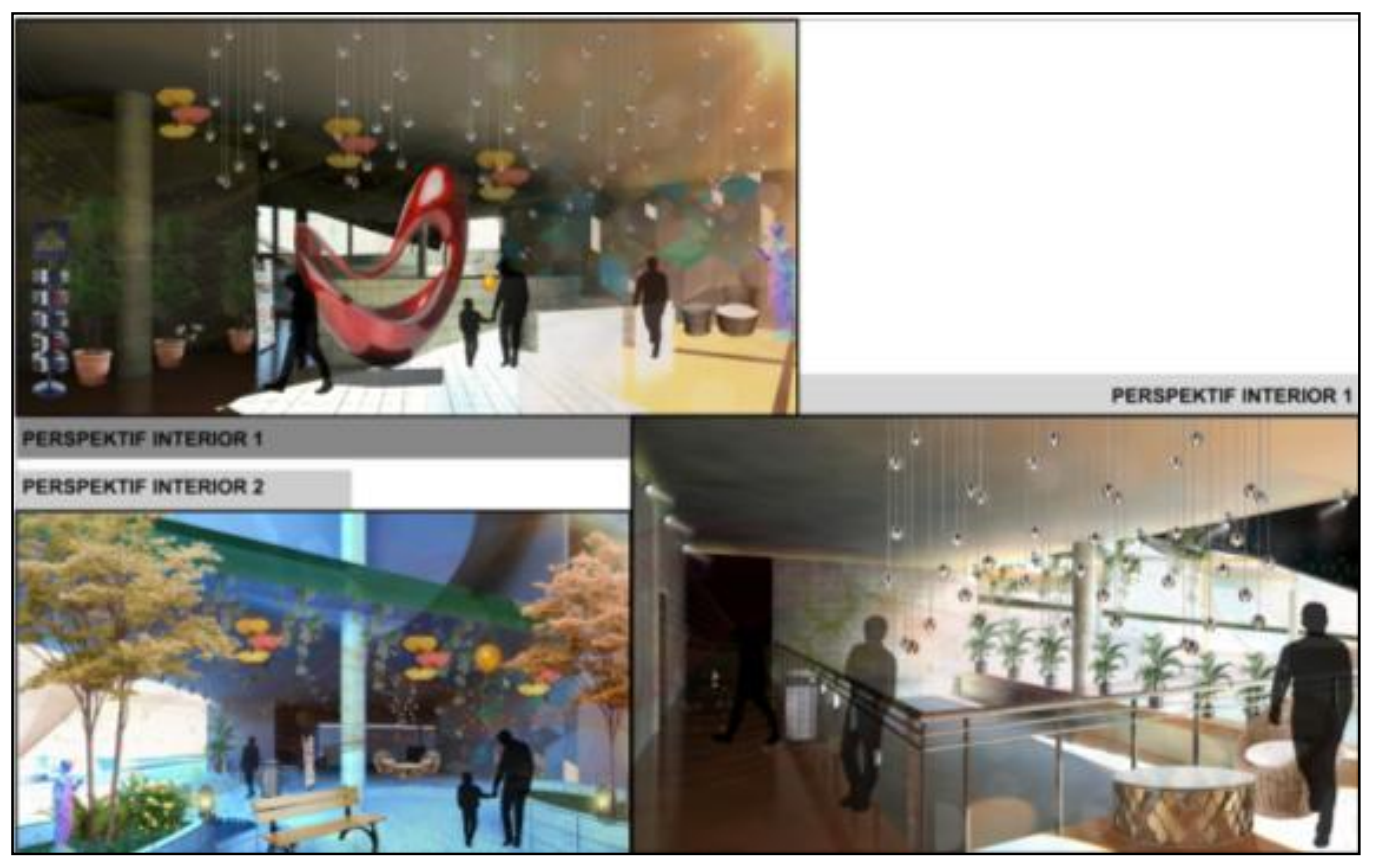

Gambar 8. Perspektif Interior

Sumber: Penulis, 2019

\section{KESIMPULAN DAN SARAN}

Coffee Grounds Innovation dan Extreme Gym berperan sebagai wadah bagi para start up yang menekuni kopi sebagai lapangan usaha, membentuk keakraban antara komunitas pencinta kopi dan pencinta alam dan menjadi sarana rekreasi bagi pencinta alam, membentuk komunitas yang peduli akan lingkungan (back to nature) melalui aplikasi kopi sebagai bahan dasar. 


\section{REFERENSI}

Desmita. (2011). Psikologi Perkembangan Peserta Didik. Bandung:Remaja Rosdakarya.

Fahyuni, E. F., Istikomah. (2016). Psikologi Belajar \& Mengajar. Sidoarjo:Nizamia Learning Center.

Haryanto, B. (2004). Psikologi Pendidikan dan pengenalan Teori-teori Belajar, Sidoarjo:Universitas Muhammadiyah Sidoarjo.

Jahja, Y. (2013). Psikologi Perkembangan. Jakarta:Kencana Prenamadia Group.

Kari, J. (2008). Basic Design Methods. Benhil: Boston.

Moneo, R. (1978). On Typology, Oppositions, 22-45.

Sebastian, Y. (2016). Generasi langgas: Milenials Indonesia. Jagakarsa: Cianjur.

Syah, M. (2011). Psikologi Pendidikan Dengan Pendekatan Baru. Bandung : PT.Remaja Rosda Karya.

Teh, S. W., Lianto, F., Trisno., R. (2018). The Truss Structure System. Civil Engineering and Technology,2460-2469

Tsukamoto,Y, Kaijima, M. (2010). Behaviorology.New York: Rizzoli.

https://www.aa.com.tr/id/headline-hari/cara-komunitas-bersihkan-gunung-darisampah/1383102 (diakses tanggal 24 Maret 2019)

http://e-journal.uajy.ac.id/13294/3/TI074602.pdf (diakses tanggal 16 Februari 2019)

https://hutanitu.id/forest-festival-rayakan-hutan-indonesia/ (diakses tanggal 20 April 2019)

https://recyclearea.wordpress.com/2010/05/10/pengolahan-limbah-kopi/ (diakses tanggal 16 Februari)

https://www.asiconferences.com/wp-content/uploads/2016/11/Milenial-Life-Stages-ReportApril-2016.pdf (diakses tanggal 22 Januari 2019)

http://www.bbc.com/future/story/20170605-the-psychology-behind-your-citys-design (diakses tanggal 22 Januari 2019)

https://www.cnbc.com/2018/08/20/how-much-milenials-spend-at-restaurants-eachmonth.html (diakses tanggal 22 Januari 2019)

https://www.cnnindonesia.com/gaya-hidup/20171001142321-262-245381/mengulikkomunitas-unik-pencinta-kopi (diakses tanggal 24 Maret 2019)

https://www.myrecipes.com/extracrispy/milenials-spend-more-at-bars-restaurants-and-cafesthan-other-generations (diakses tanggal 24 Maret 2019)

http://www.pewresearch.org/fact-tank/2019/01/17/where-milenials-end-and-generation-zbegins/ (diakses tanggal 22 Januari 2019)

https://www.un.org/sustainabledevelopment/sustainable-development-goals/(diakses tanggal 16 Februari 2019) 
